\title{
PENINGKATAN BUDAYA HORMAT MAHASISWA MELALUI PEMBIASAAN PADA MATERI PENDIDIKAN PANCASILA DI FAKULTAS ILMU SOSIAL DAN ILMU POLITIK DI UNIVERSITAS 17 AGUSTUS 1945 JAKARTA UTARA
}

\author{
Raymundus I Wayan Ray \\ Dosen Administrasi Publik \\ Universitas 17 Agustus 1945 Jakarta \\ raymundus.ray@uta45jakarta.ac.id
}

\begin{abstract}
The purpose of this research is to gain empirical data about the effort to improve the behavior of Respect students through Three Semester Conditioning Gansal academic year 2015/2016 at the Faculty of social science and political science University, August 17, 1945. The object in this study is the whole student faculty of social science and political science Public Administration science courses totalling 35 people. The research method used was the Research Action (Action Research). This action research conducted with 3 cycles, where each cycle consisted of Planning (Planning) Act (Action), observation, (Observing), and reflection.

From the results of the assessment cycle I found that out of the 35 students academic year 2015/2016, 25 students or 71,42\% meet the graduation criteria is minimal. While 10 students or $28,57 \%$ has not met the graduation criteria in the process and associated costs. This means that 25 students have been showing the symptoms of change in College, while 10 students has not shown significant changes. So need to make improvements to the Planning Cycle through lecture II because it has not yet reached $75 \%$ meet the criteria of graduation courses. While the average value of graduation college student earnings only reached $75 \%$ of students meet college graduation. While the average value of graduation students gain only mecapai 69.30\%. After through the implementation cycle cycle I, II and III showed that an effort improve the culture of respect students through learning civics changes i.e. manners of college students in the process of a lecture from the culture of respect for $57 \%$ in cycle I became $70 \%$ in cycle II. While in the III cycle obtained average results of $94 \%$.
\end{abstract}

Keywords : Culture of honor and Conditioning On Civics

\begin{abstract}
ABSTRAK
Tujuan penelitian ini adalah untuk mendapatkan data secara empiris tentang Upaya Meningkatan Perilaku Hormat Siswa Melalui Pembiasaan Semester Tiga Gansal Tahun Akademik 2015/2016 di Fakultas Ilmu Sosial dan Ilmu Politik Universitas 17 Agustus 1945 Jakarta. Objek dalam penelitian ini adalah seluruh mahasiswa Fakultas Ilmu Sosial
\end{abstract}


dan Ilmu Politik Program Studi Ilmu Administrasi Publik berjumlah 35 orang. Metode penelitian yang digunakan adalah Penelitian Tindakan (Action Research). Penelitian Tindakan, yaitu jenis penelitian kualitatif. Penelitian tindakan ini dilakukan dengan 3 siklus, dimana masing-masing siklus terdiri dari Perencanaan (Planning) Tindakan (Action), Observasi, (Observing), dan Refleksi. (Reflekting)

Dari hasil penilaian pada siklus I ditemukan bahwa dari 35 mahasiswa Tahun Akademik 2015 /2016, 25 mahasiswa atau 71,42 \% memenuhi batas kriteria kelulusan minimal. Sedangkan 10 mahasiswa atau 28,57 \% belum memenuhi batas kriteria kelulusan dalam proses perkuliahan. Hal ini mengandung arti bahwa 25 mahasiswa tersebut telah menunjukkan gejala perubahan dalam kuliahnya, sedangkan 10 siswa belum menunjukkan perubahan yang signifikan. Sehingga perlu melakukan perbaikan perencanaan perkuliahan melalui Siklus II karena belum mencapai $75 \%$ memenuhi kriteria kelulusan perkuliahan. Sedangkan nilai rata-rata kelulusan kuliah perolehan mahasiswa hanya mencapai $75 \%$ siswa memenuhi kelulusan kuliah. Sedangkan nilai rata-rata kelulusan perolehan mahasiswa hanya mecapai 69,30 \%. Setelah melalui pelaksanaan siklus I, II dan siklus III penelitian menunjukkan bahwa upaya meningkatkan budaya hormat mahasiswa melalui pembelajaran pendidikan Pancasila terjadi perubahan yakni tata krama mahasiswa dalam proses perkuliahan dari budaya hormat $57 \%$ pada siklus I menjadi $71 \%$ pada siklus II. Sedangkan pada siklus III diperoleh hasil rata-rata $94 \%$.

\section{Kata Kunci : Budaya Hormat, dan Pembiasaan Pada Materi Pendidikan Pancasila}

\section{A. PENDAHULUAN}

Dalam pelaksanaan pembangunan nasional dibutuhkan sumber daya manusia yang handal, mandiri, profesional, berkualitas, baik dari segi mental spiritual maupun dari material spiritual. Dengan tingkat kualitas yang baik maka seseorang diharapkan mampu dapat mengaktualisasikan disiplin ilmu berdasarkan pada bidang masing-masing, sehingga dapat dijadikan modal dalam pelaksanaan pembangunan.Keberhasilan proses pendidikan ditentukan oleh kerjasama yang harmonis antar keluarga, kampus dan masyarkat. Kerjasama antara keluarga, kampus dan masyarakat merupakan tritunggal penanggung jawab pendidikan. Pendidikan ini harus dijalin dengan erat. Hal ini disebabkan karena kehidupan seseorang selalu mendapat pengaruh dari ketiga lingkungan tersebut. Dalam kehidupan sehari-hari cukup sering kita menemui mahasiswa/mahasiswi yang kelihatan lugu ternyata mahasiswa yang suka berkata kasar, berbohong, tidak menghargai orang lain dan sebagainya. Kondisi ini sangat memprihatinkan para orang tua dan para dosen sebagai pendidik. Hal tersebut tidak dapat dipungkiri karena dalam kesehariannya mahasiswa/mahasiswi selalu dihadapkan pada kondisi keluarga, kampus maupun masyarakat yang selalu berorientasi pada hal keduniaan semata dengan mengesampingkan moral, etika dan sopan 
santun sebagai landasan utama bangsa Indonesia.

Di Indonesia kini sedang mengalami petalogi sosial yang amat kronis. Bahkan sebagian mahasiswa dan masyarakat kita tersebut dari peradaban ketimuran yang beradab, santun, budaya hormat dan beragama. Ini timbul dari akibat masyarakat Indonesia yang beragam dan menelan peradaban barat tanpa adanya seleksi yang matang. Disamping itu sistem pendidikan di Indonesia yang berorientasi pada peningkatan intelektual semata tanpa memperhatikan peningkatan sisi moral dan pembiasaan serta etika yang merupakan warisan terbaik bangsa kita.Akibatnya, pada pribadi masyarakat dan mahasiswa pada umumnya menimbulkan efek-efek yang buruk, seperti tidak adanya sikap hormat mahasiswa terhadap orang-orang yang berada di lingkungan kampus baik itu terhadap teman-teman sebaya bahkan yang lebih memprihatinkan yaitu tidak ada lagi budaya hormat kepada dosen dan orang-orang yang berada di lingkungan kampus.Untuk merespon gejala yang kemerosotan pembiasaan ini, maka peningkatan dan intensitas pelaksanaan pendidikan pembiasaan di kampus merupakan tugas yang sangat penting dan sangat mendesak bagi kita dan perlu dilaksanakan secara komprehensif dan dengan menggunakan strategi serta model pendekatan secara terpadu, yaitu dengan melibatkan semua unsur yang terkait dalam proses pembelajaran atau pendidikan seperti : dosen-dosen, Pembimbing akademik, orang tua mahasiswa dan masyarakat. Tujuan pendidikan pembiasaan pada materi pendidikan Pancasila tidak sematamata untuk menyiapkan mahasiswa/mahasiswi untuk menelan mentah konsep-konsep materi pendidikan Pancasila, tetapi yang lebih penting adalah terbentuknya karakter yang baik. Pendidikan Pancasila dan Kewarganegaraan (PKn) merupakan bidang studi yang dimaksudkan sebagai wahana untuk mengembangkan dan melestarikan nilai-nilai luhur dan moral yang berakar pada budaya bangsa Indonesia. Nilai luhur tersebut diharapkan dapat terwujud dalam bentuk perilaku kehidupan sehari-hari para mahasiswa, baik sebagai individu, anggota masyarakat maupun mahluk ciptaan Tuhan Yang Maha Esa.

Di samping itu, pendidikan Pancasila juga dimaksudkan membekali peserta didik dengan budi pekerti, pengetahuan dan kemampuan dasar berkenaan dengan hubungan antar warga negara serta pendidikan pendahuluan bela negara, agar mereka menjadi warga Negara yang dapat dihandalkan oleh bangsa dan negara. Dalam pertumbuhan dirinya budaya hormat mahasiswa di kampus juga banyak dipengaruhi dari lingkungan kehidupannya yaitu lingkungan rumah tangga, kampus dan lingkungan masyarakat sekitarnya. Teori pembiasaan adalah teori tentang proses pendidikan yang berlangsung dengan jalan membiasakan seseorang untuk bertingkah laku, berbicara, berpikir dan melakukan aktivitas tertentu menurut 
kebiasaan yang baik. Pembiasaan (conditioned) merupakan proses pembentukan sikap dan perilaku yang relatif menetap dan bersifat otomatis melalui proses pembelajaran yang berulang-ulang. Sikap atau perilaku yang menjadi kebiasaan mempunyai ciri; perilaku tersebut relatif menetap, umumnya tidak memerlukan fungsi berpikir yang cukup tinggi, misalnya untuk dapat mengucapkan salam cukup fungsi berpikir berupa mengingat atau meniru saja, bukan sebagai hasil dari proses kematangan, tetapi sebagai akibat atau hasil pengalaman atau belajar, dan tampil secara berulang-ulang sebagai respons terhadap stimulus yang sama. Teori pembiasaan ini dipopulerkan oleh Ivan Pavlov dan B.F. Skinner. Proses pembiasaan berawal dari peniruan, selanjutnya dilakukan pembiasaan di bawah bimbingan orang tua, dan dosen, orang tua akan semakin terbiasa. Bila sudah menjadi kebiasaan yang tertanam jauh di dalam hatinya, maka orang tersebut kelak akan sulit untuk berubah dari kebiasaannya itu. Misalnya ia akan melakukan shalat berjamaah bila waktu shalat tiba, tidak akan berpikir panjang apakah shalat dulu atau melakukan hal lain, apakah berjamaah atau nanti saja shalat sendirian. Hal ini disebabkan karena kebiasaan itu merupakan perilaku yang sifatnya otomatis, tanpa direncanakan terlebih dahulu, berlangsung begitu saja tanpa dipikirkan lagi. Proses pembiasaan dalam pendidikan Pancasila merupakan hal yang penting terutama bagi mahasiswamahasiswa semester awal.

\section{B. RUMUSAN MASALAH}

1. Apa saja faktor penyebab terjadinya penurunan budaya hormat (respect) mahasiswa terhadap dosennya?

2. Bagaimana dampak menurunya budaya hormat terhadap dosen? 4) Bagaimana cara mengembalikan budaya hormat (respect) mahasiswa terhadap dosen?

3. Bagaimanakah upaya meningkatkan budaya hormat mahasiswa melalui pembiasaan pada materi pendidikan Pancasila di Universitas 17 Agustus 1945 Jakarta?

\section{KAJIAN TEORI}

\section{Budaya Hormat}

Kamus Umum Bahasa Indonesia milik W.J.S. Poerwadarminta Sopan adalah hormat dan takzim (akan,kepada) atau tertib menurut adat yang baik. Santun adalah halus dan baik budi bahasanya,tingka lakunya atau sabar dan tenang.

Ki Hajar Dewantara (Adam, 2011) Kebudayaan diartikan sebagai buah budi manusia, adalah hasil perjuangan manusia terhadap dua pengaruh kuat, yakni zaman dan alam yang merupakan bukti kejayaan hidup manusia untuk mengatasi berbagai rintangan dan kesukaran didalam hidup dan penghidupannya guna mencapai 
keselamatan dan kebahagiaan yang pada lahirnya bersifat tertib dan damai.

Menurut Koentjoroningrat (Adam, 2013) Kebudayaan adalah keseluruhan sistem gagasan, tindakan dan hasil karya manusia dalam rangka kehidupan masyarakat yang dijadikan milik dari manusia dengan belajar.

Jadi dari beberapa definisi dapat disimpulkan bahwa budaya hormat atau sopan santun adalah cara hidup yang diciptakan secara turun temurun oleh sekelompok orang dalam memperlakukan orang lain secara halus dan baik, baik itu budi bahasa maupun tingkah laku dengan menggunakan akal budi dan nurani.

\section{Pembiasaan}

Teori pembiasaan dalam pendidikan adalah yang proses pendidikan yang berlangsung dengan jalan membiasakan mahasiswa untuk bertingkah laku, berbicara, berpikir dan melakukan aktivitas tertentu menurut kebiasaan yang baik, sebab tidak semua hal yang dapat dilakukan itu baik.(http://prodibpi.wordpress.com/2010 /08/05 ). Menurut N. Purwanto (2010) 1) Kebiasaan adalah tingkah laku yang cenderung selalu ditonjolkan oleh individu dalam menghadapi keadaan tertentu atau ketika berada dalam keadaan tertentu.Menurut N. Purwanto (2010) .2) Kebiasaan merupakan proses "Internalisasi" dari norma masyarakat, dan adanya kematangan dari sudut organik biologik yang diwujudkan dalam perilaku sadar. 3)Kebiasaan merupakan hasil dari rangkaian rangsang dan jawaban yang dipelajari oleh anak dan dilakukan secara berkesinambungan.

Jadi latihan pembiasaan merupakan upaya yang intensif untuk menciptakan lingkungan (rangsangan) sebagai sumber dari timbulnya tingkah laku, yang cenderung selalu ditonjolkan oleh individu sebagai proses internalisasi dari norma-norma lingkungan agar diperoleh kematangan dan perkembangan kepribadian yang optimal.

\section{Pendidikan Pancasila}

Ir. Soekarno Pancasila adalah isi jiwa bangsa Indonesia yang turuntemurun sekian abad lamanya terpendam bisu oleh kebudayaan Barat. Dengan demikian, Pancasila tidak saja falsafah negara, tetapi lebih luas lagi, yakni falsafah bangsa Indonesia.

Panitia Lima Pancasila adala lima asas yang merupakan ideologi negara. Kelima sila itu merupakan kesatuan yang tidak dapat dipisahkan satu sama lain. Hubungan antara lima asa erat sekali, berangkaian, dan tidak berdiri sendiri. Prof. Drs. Mr. Notonegoro Pancasila merupakan dasar falsafah negara Indonesia

Pada Lambang Negara RI “ Garuda Pancasila"Pancasila adalah dasar falsafah dan ideologi negara yang diharapkan menjadi pandangan hidup bangsa Indonesia sebagai dasar pemersatu, lambang persatuan dan kesatuan, serta sebagai pertahanan bangsa dan negara Indonesia. Bung Yamin Pancasila adalah weltanschauung, 
falsafah negara Republik Indonesia, bukan satu agama baru.

\section{Kerangka Pikir}

Budaya Hormat sangat berpengaruh terutama pada kesadaran mahasiswa untuk menerapkan materi pendidikan Pancasila. Karena pada mahasiswa semester 1 (awal) merupakan masa perubahan dari tingkat SLA kejenjang yang lebih tinggi adalah pembentukan kepribadian sudah harus dilakukan sejak usia dini. Dengan pendidikan Pancasila yang ditempuhnya diharapkan memperoleh dasar-dasar pengetahuan dan ketrampilan yang penting artinya demi keberhasilan dalam penyesuaian hidup dimasa dewasa nanti. Pada usia ini mahasiswa akan mengikuti pola kehidupan dan tingkah laku orang dewasa (dosen).

Peranan orang dewasa disini harus mampu menerapkan tingkah lakunya sesuai dengan norma dan pekerti luhur.Yang menjadi kerangka pikir dalam penelitian ini adalah diduga bahwa melalui pembiasaan pada materi pendidikan Pancasila dapat meningkatkan budaya hormat mahasiswa pada Fakultas Ilmu Sosial dan Ilmu Politik di Universitas 17 Agustus 1945 Jakarta.

\section{Hipotesis Tindakan}

Dugaan dari uraian tersebut di atas, maka hipotesis tindakan dalam penelitian ini adalah bahwa pembiasaan pada materi pendidikan Pancasila dapat meningkatkan budaya hormat mahasiswa pada
Fakultas Ilmu Sosial dan Ilmu Politik di Universitas 17 Agustus 1945 Jakarta.

\section{METODE PENELITIAN}

\section{Jenis Penelitian}

Penelitian ini adalah jenis penelitian kualitatif, dengan pendekatan studi menggunakan metode Penelitian Tindakan (Action Reseach). Penelitian tindakan diartikan sebagai penelitian yang berorientasi pada penerapan tindakan dengan tujuan peningkatan mutu atau pemecahan masalah pada sekelompok subyek yang diteliti dan mengamati tingkat keberhasilan atau akibat tindakannya, untuk kemudian diberikan tindakan lanjutan yang bersifat penyempurnaan tindakan atau penyesuaian dengan kondisi dan situasi sehingga diperoleh hasil yang lebih baik.

\section{Prosedur Tindakan}

Penelitian tindakan ( Action Reseach) ini menggunakan 3 (tiga) siklus, dimana setiap siklus terdiri dari 4 (empat)macam, yaitu :

Penelitian tindakan adalah suatu bentuk penelitian reflektif dan kolekif yang dilakukan oleh peneliti dalam situasi social untuk meningkatkan budaya hormat mahasiswa melalui pembiasaan pada materi Pendidikan Pancasila di Fakultas Ilmu Sosial dan Ilmu Politik Universitas 17 Agustus 1945 Jakarta. Penelitian ini menggunakan model Kurt Lewin, konsep pokok penelitian tindakan Kurt Lewin terdiri dari empat komponen yaitu: 1) Perencanaan (Planning). 
2)Tindakan (Acting)3) Pengamatan (observing), dan 4) Refleksi (Reflecting)

Hubungan keempat komponen tersebut dipandang sebagai satu siklus yang dapat digambarkan sebagai berikut :

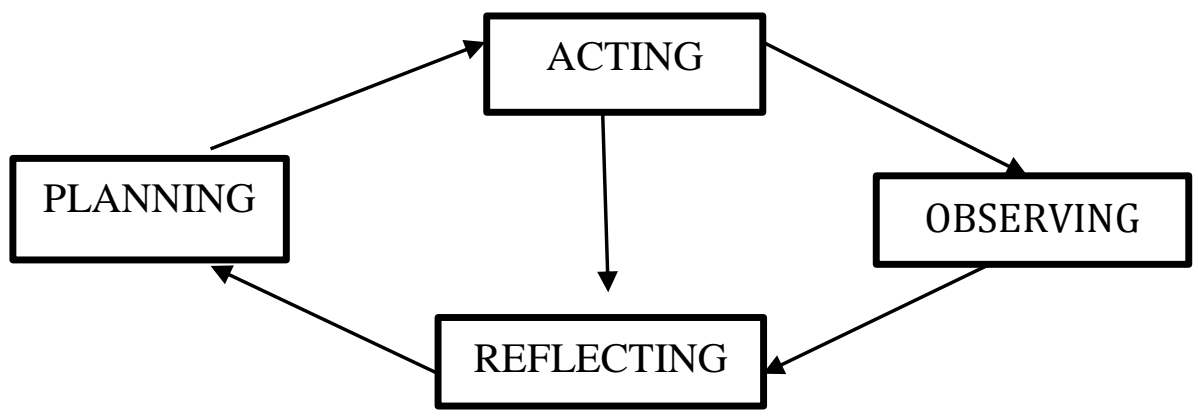

Siklus Selanjutnya

\section{Gambar 1 : Desain Action Research}

\section{Sumber Data}

Adapun sumber data dalam penelitian terdiri dari 2 (dua) macam yaitu :

1. Informan. Adapun yang menjadi informan dalam penelitian ini adalah mahasiswa semester 1 Ilmu Administrasi Publik 14 orang, Ilmu Komunikasi 16 orang dan Ilmu Politik 5 orang semester Ganjil 2015/2016 di Fakultas Ilmu Sosial dan Ilmu Politik Universitas 17 Agustus 1945 Jakarta.

2. Kay Informan. Sedangkan yang menjadi kay informan dalam penelitian ini adalah dekan, kaprodi, dosen (teman sejawat), dan mahasiswa di Fakultas Ilmu Sosial dan Ilmu Politik Universitas 17 Agustus 1945 Jakarta.

\section{Teknik Pengumpulan Data}

Dalam penelitian ini teknik yang digunakan untuk mengumpulkan data adalah sebagai berikut : 1. Wawancara. Wawancara ini dilakukan untuk melengkapi dan memperkuat data dan informasi yang diperoleh dari hasil angket serta untuk mendapatkan data yang tidak dapat dijangkau oleh angket dan observasi di lapangan. Selanjutnya wawancara tersebut ditujukan pada dekan, kaprodi, dosen dan mahasiswa yang diperlukan peneliti, yaitu tentang peningkatan budaya hormat mahasiswa melalui pembiasaan pada materi pendidikan Pancasila di Fakultas Ilmu Sosial dan Ilmu Politik Universitas 17 Agustus $1945 \quad$ Jakarta. 2. Observasi/Pengamatan. Untuk mendapatkan gambaran penelitian tentang peningkatan budaya hormat mahasiswa melalui pembiasaan pada materi 
pendidikan Pancasila di Fakultas Ilmu Sosial dan Ilmu Politik Universitas 17 Agustus 1945 Jakarta. Maka penulis melakukannya dengan pengamatan langsung terhadap mahasiswa-mahasiswi dosen, kaprodi dan dekan. 3.Dokumentasi. Peneliti dalam hal ini menggunakan studi literatur untuk melengkapi keobjektipan dan menunjang data yang diperlukan, serta untuk membuktikan keobjektipan dan keilmiahan dari data yang didapat dan mengadakan pencatatan yang dianggap perlu terhadap dokumen-dokumen yang menunjang kepada masalah penelitian dan dokumen ini digunakan untuk memperlihatkan latar selama kegiatan berlangsung dengan melakukan pemotretan guna mendapatkan data yang lebih lengkap dan lebih akurat. Untuk menarik perhatian mahasiswa dalam pembelajaran, maka penulis mencoba untuk memecahkan permasalahan ini dengan rencana sebagai berikut : 1) Menyusun rencana tindakan tentang budaya hormat melalui penerapan materi pendidikan Pancasila.2)Menyiapkan tugas yang akan diberikan kepada mahasiswamahasiswi yang berupa soal-soal pilihan ganda, isian, dan essay. 3) Melaksanakan program tindakan yang telah dibuat. 4) Memberikan penjelasan tentang pelaksanaan tugas tersebut serta mempersiapkan waktu dan jadwal.5) Tugas diberikan pada masing-masing mahasiswa.dan 6) Mencatat budaya hormat mahasiswa selama pelaksanaan tugas.

\section{Teknik Analisis Data}

Teknis analisis data yang digunakan dalam penelitian ini adalah sebagai berikut:

1. Reduksi data yaitu dengan memilahmilah data, data mana yang sekiranya bermanfaat dan data mana saja yang dapat diabaikan, sehingga data yang terkumpul dapat memberikan informasi yang bermakna.

2. Paparan data/ display data yaitu data yang akan ditampilkan oleh peneliti dalam bentuk narasi yang berfungsi untuk menunjukkan informasi tentang sesuatu hal berkaitan dengan variabel yang satu dengan yang lain.

3. Penyimpulan data/ verifikasi data yaitu proses menarik intisari atas sajian data dalam bentuk pernyataan yang singkat dan padat, tetapi mengandung pengertian yang sangat luas.

\section{Teknik Keabsahaan Data}

Untuk memperoleh data yang akurat dan autentik, maka teknik kalibrasi keabsahan data yang dipergunakan adalah sebagai berikut :

1. Ketekunan pengamatan, yaitu peneliti berusaha semaksimal mungkin melakukan pengamatan dan wawancara secara tekun, teliti, dan konsisten kepada informan dan key informan, agar memperoleh data yang valid dan reliable.

2. Saturation, yaitu kegiatan melakukan kroscek kepada teman sejawat (dosen) 
3. Trianggulasi, yaitu kegiatan melakukan kroscek kebenaran jawaban informan kepada key informan.

\section{Kriteria Keberhasilan Penelitian}

1. Siklus I Budaya Hormat Mahasiswa dapat meningkat sebesar $57 \%$

2. Siklus II Budaya Hormat Mahasiswa dapat meningkat sebesar $71 \%$

3. Siklus III Budaya Hormat mahasiswa dapat meningkat sebesar $94 \%$

\section{E. HASIL PENELITIAN DAN PEMBAHASAN}

\section{Deskripsi Tindakan}

Setelah melalui proses refleksi, diskusi dan proses observasi dengan mitra kerjasama (teman sejawat) dari pelaksanaan siklus I, siklus II dan siklus III di peroleh temuan-temuan yang dapat diangkat sebagai suatu teori baru dalam konteks meningkatkan budaya hormat mahasiswa melalui pembiasaan pada materi pendidikan Pancasila antara lain :

1. Rendahnya budaya hormat mahasiswa pada siklus I disebabkan oleh beberapa faktor antara lain a) Kurangnya orang tua dalam membimbing anaknya atau kurangnya hubungan yang harmonis antara orang tua dengan anak.b) Tumbuhnya anak dari keluarga yang broken home atau bisa juga berasal dari faktor lingkungan sosial. c) Pengertian pemahaman serta penerapan budaya hormat mahasiswa belum dipahami sepenuhnya oleh mahasiswa yang bersangkutan.

2. Keadaan Budaya Hormat Mahasiswa

a. Data Siklus I pembiasaan mahasiswa masih rendah (sedang dan kurang), hal ini disebabkan oleh kemampuan dosen yang hanya memberi kuliah target terselesaikannya materi pendidikan Pancasila yang terdapat dalam program pembelajaran $(57 \%)$

b. Adanya anggapan dosen , bahwa semua mahasiswa sudah mengetahui dan memahami nilai-nilai budaya hormat dalam pembelajaran materi pendidikan Pancasila.

c. Kurangnya sosialisasi dan realisasi nilai-nilai budaya hormat dalam pembiasaan oleh dosen yang disesuaikan dengan materi perkuliahan.

d. Dosen sudah menjelaskan pentingnya pembelajaran budaya hormat dalam meningkatkan pembiasaan pada materi pendidikan Pancasila untuk mahasiswa, dan menjelaskan komponen budaya hormat.

e. Pada siklus II ini sudah ada perubahan peningkatan budaya 
hormat mahasiswa dengan

katagori nilai baik 25

mahasiswa dan nilai sedang 10

mahasiswa (71\%). Hal ini

disebabkan tentang pentingnya

pembelajaran budaya hormat

dalam Pembiasaan pada materi

pendidikan Pancasila dalam

kehidupan sehari-hari.

f. Dosen menjelaskan komponen

budaya hormat kepada

mahasiswa yang dibarengi

dengan penerapan dalam

kehidupan sehari-hari terutama

di kampus sehingga mahasiswa mulai tertarik walaupun masih ada beberapa mahasiswa yang belum mengerti dan memahami.

g. Pada siklus III ini sudah ada peningkatan budaya hormat yang sangat signifikan (dengan nilai budaya hormat baik sejumlah 33 dan nilai kurang sejumlah 2 mahasiswa $=94 \%$ ).

Hal ini disebabkan oleh perubahan sikap tata krama mahasiswa, karena sudah mengerti dan memahami pentingnya pembelajaran pembiasaan pada materi pendidikan Pancasila dan dalam kegiatan tindakan dosen dalam penerapan pembiasaan sudah bisa menarik perhatian mahasiswa, karena anak/mahasiswa disuruh mempraktikkan nilai-nilai pembiasaan pada materi pendidikan Pancasila dalam bentuk budaya hormat di ruang kuliah pada saat proses belajar mengajar/ perkuliahan yang sedang berlangsung.

h. Pada akhir kegiatan terdapat fase refleksi dari dosen dengan maksud untuk mengetahui sejauh mana manfaat atau pentingnya pembelajaran pembiasaan pda materi pendidikan Pancasila bagi mahasiswa untuk meningkatkan budaya hormat dan untuk mengetahui kondisi mahasiswa setelah melalui tahapan proses tindakan.

Dari hasil observasi terhadap mahasiswa pada siklus III memperoleh data bahwa mahasiswa menunjukkan adanya perubahan budaya hormat karena mereka mulai berani mengingatkan temannya yang tidak berperilaku hormat. Mahasiswa sudah memiliki kesadaran yang tinggi untuk menghargai pendapat orang lain dan mulai menguasai sikap yang jujur sopan santun dan sikap yang jujur dan budaya hormat dalam kebersamaan.Seletah melalui pelaksanaan siklus I, II dan siklus III penelitian menunjukkan bahwa peningkatan budaya hormat mahasiswa melalui pembiasaan pada materi pendidikan Pancasila terjadi perubahan belajar tata krama mahasiswa dalam proses belajar dari budaya hormat $57 \%$ pada siklus I menjadi $71 \%$ pada siklus II. Sedangkan pada siklus III diperoleh hasil rata rata $94 \%$.

1. Pada siklus I baru terdapat 20 atau 57\% mahasiswa dari 35 mahasiswa yang diteliti yang budaya 
hormatnya meningkat, sedangkan masih ada 15 mahasiswa lagi yang belum menunjukan adanya peningkatan.

2. Pada siklus II telah terjadi peningkatan dari 20 mahasiswa menjadi 25 atau $71 \%$ mahasiswa dari 35 mahasiswa yang diobservasi, dan masih tersisa 10 mahasiswa yang masih belum menunjukan adanya peningkatan budaya hormatnya.

3. Namun pada siklus III telah terjadi peningkatan yang signifikan karena telah ada 33 mahasiswa atau 94\% yang telah mencapai peningkatan budaya hormatnya dengan baik, dan hanya ada 2 orang mahasiswa yang belum mencapai hasil yang diinginkan.

\section{Pembahasan}

\section{a. Siklus I}

Pada siklus ke satu ini hasil observasi menunjukkan adanya kekurang pemahaman materi pendidikan Pancasila dan belum adanya perubahan budaya hormat , maka aktivitas dan peran mahasiswa kurang nampak dalam pembelajaran/perkuliahan. Melalui pembahasan berdasarkan analisa data kualitaif hasil penelitian tindakan diperoleh hal-hal tentang bagaimana Mengupayakan agar mahasiswa dapat menerapkan pembiasaan pada materi pendidikan Pancasila terutama dengan materi pada program tindakan meningkatkan keaktifan belajar mahasiswa pada pembelajaran materi pendidikan Pancasila, dapat menerapkan pembiasaan seperti sopan santun, ketertiban, menghargai orang lain, tolong menolong, jujur, dan menghormati orang lain. Hasil dialog kolaboratif dan diskusi untuk meningkatkan budaya hormat melalui pembiasaan pada materi pendidikan Pancasila diharapkan memperoleh hasil yang semakin baik yang ditunjukkan pada waktu melaksanakan tindakan kelas.

Hasil pengamatan peneliti yang didukung oleh mitra kolaborasi dalam hal ini teman sejawat/dosen sejawat selalu memberikan proses pembelajaran, serta kompetensi yang ingin dicapai serta membimbing mahasiswa yang bertujuan untuk memahami hakekat budaya hormat melalui penerapanmateri pendidikan Pancasila. Peneliti melakukan pengamatan terhadap beberapa masalah yaitu : 1) Sopan Santun, 2) Ketertiban, 3) Menghargai Orang Lain, 4)Tolong Menolong, 5)Berbuat Jujur dan 6) Menghormati Orang Lain. Dari enam aspek yang diamati ternyata mahasiswa masih rendah, karena dari hasil observasi terhadap budaya hormat dengan menggunakan instrumen pedoman observasi pada siklus I. Berdasarkan pada pengamatan komponen budaya hormat siklus I 20 mahasiswa hasilnya baik ,5 mahasiswa hasilnya sedang, dan 10 mahasiswa kurang peningkatannya.

Hasil observasi peningkatan budaya hormat mahasiswa dapat dilihat pada table 1 di bawah ini : 
Tabel 1

Hasil Observasi siklus I

Peningkatan Budaya Hormat Mahasiswa Melalui Pembiasaan Pada Materi Pendidikan Pancasila

\begin{tabular}{|c|l|c|c|c|c|l|}
\hline No. & \multicolumn{1}{|c|}{$\begin{array}{c}\text { Aspek yang } \\
\text { diamati/diukur }\end{array}$} & \multicolumn{3}{|c|}{ Hasil Observasi } & Jumlah & \multicolumn{1}{|c|}{ Keterangan } \\
\cline { 2 - 6 } & Baik & Sedang & Kurang & Siswa & \\
\hline 1 & Sopan santun & 4 & 2 & 3 & 9 & Siklus I : dari 35 \\
2 & Ketertiban & 4 & 2 & 2 & 8 & mahasiswa yang \\
3 & Menghargai orang & 3 & 1 & 3 & 7 & baru meningkat \\
4 & lain & 3 & - & 2 & 5 & budaya hormatnya \\
5 & Tolong menolong & 3 & - & - & 3 & 20 mahasiswa (57 \\
6 & Berbuat jujur & 3 & - & - & 3 & $\%$ dan 15 \\
& Menghormati orang & & & & & mahasiswa (43\%) \\
& lain & & & & & $57 \%$ \\
\hline \multicolumn{2}{|l|}{ Jumlah melum meningat } \\
\hline
\end{tabular}

\section{b. Siklus II}

Programn tindakan pada siklus II hampir sama dengan kegiatan program tindakan pada siklus I yang membedakan Siklus I dengan Siklus II adalah sistematika kegiatan inti yang terjadi pada Siklus I diperbaiki pada Siklus II.

Berdasarkan hasil observasi, wawancara dan refleksi mitra kolaboratif yang terdiri dari peneliti dan dosen materi pendidikan Pancasila pada siklus II diperoleh temuan tentang sopan santun, ketertiban, menghargai orang lain, tolong menolong, berbuat jujur, dan menghormati orang lain menunjukan hasil yang semakin baik.

Dalam proses tindakan pada siklus II dilakukan perbaikan pada rencana program tindakan dengan mengutamakan perbaikan ada pola langkah-langkah kegiatan tindakan. Kesalahan tindakan yang terjadi pada siklus I segera diperbaiki pada siklus II yang juga terdiri dari kegiatan perencanaan tindakan, observasi, dan refleksi yang dirancang berdasarkan kesalahan, kelemahan, dan kekurangan yang sudah terjadi pada siklus sebelumnya. Perbaikan siklus I melalui pelaksanaan tahapan siklus II dengan sangat memperhatikan sebagai kesalahan, kelemahan dan kekurangan hasil refleksi pada siklus I dilakukan perbaikan secara sistematis terutama terlihat dari observasi mitra kolaborasi tergambar pada rencana program tindakanyang ditunjang dengan langkahlangkah pelaksanaan proses belajar mengajar/perkuliahan yang lebih baik.

Dari hasil penilaian skala sikap dan pembelajaran pada siklus ditemukan bahwa dari 35 mahasiswa pada semester awal (semester 1) Prodi Ilmu 
Administrasi Publik, Prodi Ilmu mahasiswa masih memperoleh hasil Komunikasi dan Prodi Ilmu Politik Fakultas Ilmu Sosial dan Ilmu Politik UTA' 45 Jakarta tahun akdemik 2015/2016, 25 mahasiswa baik, memperoleh hasil sedang 3 mahasiswa 7

kurang mengalami peningkatan. Hasil observasi peningkatan budaya hormat mahasiswa dapat dilihat pada table 2 di bawah

Tabel 2

Hasil Obsevasi siklus II

Peningkatan Budaya Hormat Mahasiswa Melalui Pembiasaan Pada Materi Pendidikan Pancasila

\begin{tabular}{|c|l|c|c|c|c|l|}
\hline No & \multicolumn{1}{|c|}{$\begin{array}{c}\text { Aspek yang } \\
\text { diamati/diukur }\end{array}$} & \multicolumn{3}{|c|}{ Hasil Observasi } & Jumlah & \multicolumn{1}{|c|}{ Keterangan } \\
\cline { 2 - 6 } & Baik & Sedang & Kurang & Siswa & \\
\hline 1 & Sopan santun & 6 & 2 & 2 & 10 & Siklus II : dari 35 \\
2 & Ketertiban & 4 & 1 & 1 & 6 & mahasiswa yang \\
3 & Menghargai orang lain & 4 & - & 1 & 5 & baru meningkat \\
4 & Tolong menolong & 4 & - & 1 & 5 & budaya hormatnya \\
5 & Berbuat jujur & 4 & - & 1 & 5 & 25 mahasiswa (71 \\
6 & Menghormati orang & 3 & - & 1 & 4 & $\%$ dan 10 \\
& lain & & & & & mahasiswa (29\%) \\
& & 25 & 3 & 7 & 35 & belum meningkat \\
\hline Jumlah & & & & & $71 \%$ \\
\hline
\end{tabular}

\section{c. Siklus III}

Dari hasil observasi terhadap mahasiswa pada Siklus III diperoleh data mahasiswa menunjukkan perubahan budaya hormat seperti sopan santun, ketertiban, menghargai orang lain, tolong menolong, berbuat jujur, dan menghormati orang lain menunjukkan perubahan peningkatan yang semakin baik.Selama melaksanakan program tindakan III dalam menerapkan pembiasaan pada materi pendidikan Pancasila untuk meningkatkan budaya hormat sudah menunjukkan kondisi yang semakin baik. Hasil ini terlihat pada perubahan peningkatan komponen budaya hormat sebagai berikut : Dalam proses tindakan siklus pertama pengenalan materi dilakukan dengan penerapan materi pendidikan Pancasila peneliti sambil mengamati budaya hormat dan pembiasaan mahasiswa dari segi kebersamaan, kesetia kawanan, tolong-menolong, tenggang rasa, hormat menghormati, kelayakan (kapatutan), rasa malu, kejujuran, dan pernyataan terima kasih, permintaan maaf (rasa tahu diri).

$$
\text { Dari keenam komponen }
$$

Pembiasaan yang diamati pada siklus III ini terdapat peningkatan budaya hormat 
mahasiswa secara signifikan dengan hasil dari 35 mahasiswa 33 mahasiswa hasil peningkatan tata kramanya baik, dan 2 mahasiswa hasilnya masih sedang.Hasil observasi peningkatan budaya hormat mahasiswa dapat dilihat pada table 3 di bawah ini :

Tabel 3

Hasil Obsevasi Siklus III

Peningkatan Budaya Hormat Mahasiswa Melalui Pembiasaan Pada Materi Pendidikan Pancasila

\begin{tabular}{|c|c|c|c|c|c|c|}
\hline \multirow[t]{2}{*}{ No. } & \multirow{2}{*}{$\begin{array}{c}\text { Aspek yang } \\
\text { diamati/diukur }\end{array}$} & \multicolumn{3}{|c|}{ Hasil Observasi } & \multirow{2}{*}{$\begin{array}{c}\text { Jumlah } \\
\text { Mahasiswa } \\
\end{array}$} & \multirow[t]{2}{*}{ Keterangan } \\
\hline & & Baik & Sedang & Kurang & & \\
\hline 1 & Sopan santun & 8 & 1 & - & 9 & Siklus III: dari 35 \\
\hline 2 & Ketertiban & 5 & 1 & - & 6 & mahasiswa yang \\
\hline 3 & Menghargai & 5 & - & - & 5 & meningkat secara \\
\hline 4 & orang lain & 5 & - & - & 5 & signifikan budaya \\
\hline 5 & Tolong menolong & 5 & - & - & 5 & hormat mahasiswa \\
\hline 6 & $\begin{array}{l}\text { Berbuat jujur } \\
\text { Menghormati } \\
\text { orang lain }\end{array}$ & 5 & - & - & 5 & $\begin{array}{l}\text { sebanyak } 33 \\
\text { mahasiswa ( } 94 \% \text { ) } \\
\text { dan } 2 \text { mahasiswa ( } 6 \\
\% \text { ) peningkatannya } \\
\text { sedang. }\end{array}$ \\
\hline \multicolumn{2}{|c|}{ Jumlah } & 33 & 2 & - & 35 & $94 \%$ \\
\hline
\end{tabular}

Tabel 4

Hasil Rekapitulasi Obsevasi Siklus I, II dan Siklus III

Peningkatan Budaya Hormat Mahasiswa Melalui Pembiasaan Pada Materi Pendidikan Pancasila

\begin{tabular}{|c|c|c|c|c|c|}
\hline \multirow[t]{2}{*}{ No. } & \multirow{2}{*}{$\begin{array}{c}\text { Hasil Penilaian } \\
\text { Observasi }\end{array}$} & \multicolumn{3}{|c|}{ Siklus } & \multirow[t]{2}{*}{ Keterangan } \\
\hline & & $\begin{array}{c}\mathrm{I} \\
(57 \%)\end{array}$ & $\begin{array}{c}\text { II } \\
(71 \%)\end{array}$ & $\begin{array}{c}\text { III } \\
(94 \%)\end{array}$ & \\
\hline $\begin{array}{l}1 \\
2 \\
3\end{array}$ & $\begin{array}{l}\text { Baik } \\
\text { Sedang } \\
\text { Kurang }\end{array}$ & $\begin{array}{c}20 \\
5 \\
10\end{array}$ & $\begin{array}{c}25 \\
3 \\
7\end{array}$ & $\begin{array}{c}33 \\
2 \\
-\end{array}$ & $\begin{array}{l}\text { Siklus I : } \\
\text { Budaya hormat mahasiswa dari } \\
35 \text { mahasiswa baru } 20 \\
\text { mahasiswa meningkat }=57 \% \\
\text { Siklus II : } \\
\text { Budaya hormat mahasiswa } \\
\text { dari } 35 \text { mahasiswa, } \\
\text { mengalami peningkatan }\end{array}$ \\
\hline
\end{tabular}




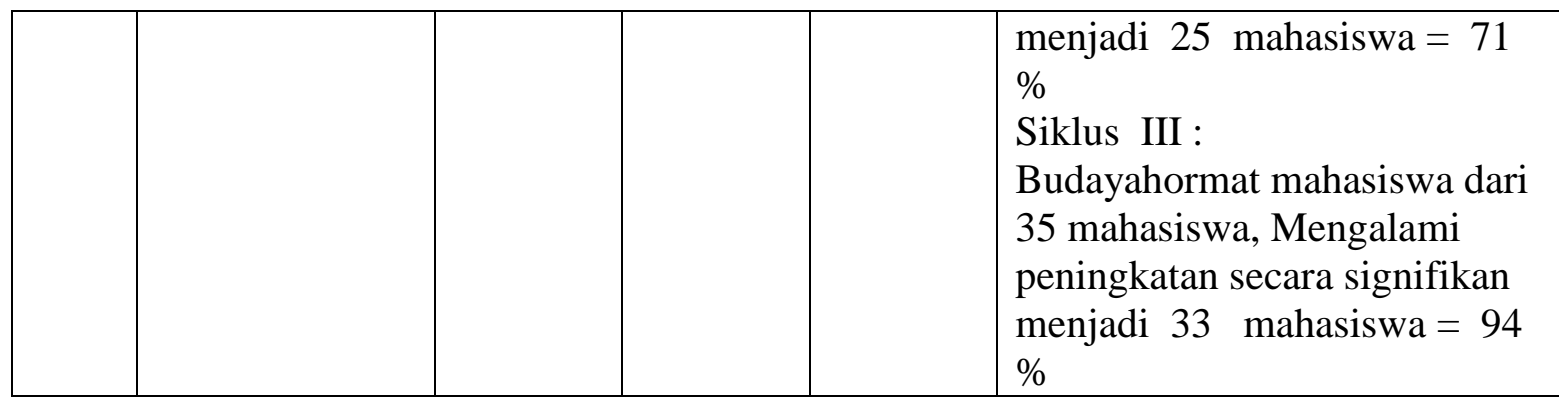

\section{F. KESIMPULAN}

Berdasarkan hasil penelitian dan analisis data terdapat adanya peningkatan perubahan budaya hormat mahasiswa melalui pembiasaan pada materi pendidikan Pancasila semester awal (semester 1) di Fakultas Ilmu Sosial dan Ilmu Politik UTA ' 45 Jakarta,maka peneliti dapat menarik kesimpulan sebagai berikut : 1. Pada siklus I baru terdapat 20 atau $57 \%$ mahasiswa dari 35 mahasiswa yang diteliti yang budaya hormatnya meningkat, sedangkan masih ada 15 mahasiswa lagi yang belum menunjukan adanya peningkatan 2. Pada siklus II telah terjadi peningkatan dari 20 mahasiswa menjadi 25 atau $71 \%$ mahasiswa dari 35 mahasiswa yang diobservasi, dan masih tersisa 10 mahasiswa yang masih belum menunjukkan adanya peningkatan budaya hormatnya.3. Akan tetapi pada siklus III telah terjadi peningkatan yang signifikan karena telah ada 33 mahasiswa atau $94 \%$ yang telah mencapai peningkatan budaya hormatnya dengan baik, dan hanya ada 2 orang mahasiswa nilainya sedang yang belum mencapai hasil yang diinginkan.

\section{G. SARAN}

Dalam kesempatan ini penulis mencoba untuk memberikan beberapa saran yang kiranya perlu untuk diperhatikan, antara lain : 1. Dosen, perlu memperkaya metode pembelajar/metode perkuliahan dalam pembentukan pembiasaan pada materi pendidikan Pancasila dan budaya hormat mahasiswa, yang biasanya dosen lebih aktif dari pada mahasiswa yang mana dapat membuat mahasiswa lebih proaktif 2. Dalam melaksanakan tugas kerjasama, dosen hendaknya memperhatikan terlebih dahulu sarana dan prasarana kampus yang tersedia sehingga akan memperlancar pelaksanaan kegiatan proses belajar mengajar dalam kelas/ruang perkuliahan.3. Dalam program tindakan hendaknya dosen materi pendidikan Pancasila lebih banyak memberikan implementasinya dalam kehidupan seharihari yang bervariasi yang berkaitan dengan budaya hormat mahasiswa.

\section{DAFTAR PUSTAKA}

Departemen Pendidikan dan Kebudayaan, 2011, Kamus Besar Bahasa Indonesia, Jakarta: Balai Pustaka 
Depdikbud, Himpunan Peraturan Perundang-undangan RI, 2014 : 1 Dirjen Pendidikan Dasar dan Menengah Depdiknas, Kewarganegaraan danPembiasaan No. 64 Tahun 2013, Proyek Pendidikan

Djumur, 2002, Bimbingan dan Penyuluhan di Sekolah, Bandung: CV Ilmu, 2010 GBHN 1999. 2004, Bandung: Pustaka Setia.

Hendayat Soetopo, 2012, Dasar atau Teori Pendidikan, Surabaya: Usaha Nasional.

Hadi Sutrisno, 2011, Metodologi Research, Yogyakarta: Fakultas Psikologi Universitas Gajah Mada Yogyakarta

Humalik, Oemar, 2014 Kurikulum dan Pembelajaran, Jakarta: Bumi Aksara.

Lembaga Ketahanan Nasional, 2009, Ketahanan Nasional, Jakarta: Balai Pustaka

Purwanto, Ngalim, 2009Prinsip-prinsip Evaluasi Pengajaran, Jakarta: Remaja Rosda Karya

Martin Handoko, 1995. Motivasi Daya Penggerak Tingkah Laku, Yogyakarta: Kanisius
Muhammad Ali, 2008. Kamus Lengkap Bahasa Indonesia Modern, Jakarta: Pustaka Arcani

Suharsimi Arikunto, 2010, Prosedur Penelitian Suatu Pendekatan Prkatek, Jakarta: Bina Aksara

Surachman, Winarno, 2009. Pengantar Interaksi Belajar Mengajar, Bandung: Tarsito 